\title{
Keynote Remarks: Re-Tooling Law and Legal Education for Food System Reform: Food Law and Policy in Practice
}

\author{
Emily M. Broad Leib*
}

Thank you for the opportunity to be with you today and to take part in this symposium on the important role law schools and lawyers can play in changing our food system. Food preferences and food choices are incredibly personal, but the way we produce and consume food, and its impacts on our environment, public health, and the safety of ourselves and others, make it a pressing societal issue as well.

Defining food law as a distinct field is relatively new. Lawyers and legal scholars from different backgrounds and perspectives, many of whom previously did not consider themselves practitioners of "Food Law," are coming together, acknowledging the interconnectedness of their work, and harnessing their diverse expertise in hopes of fostering food system change. ${ }^{1}$ As lawyers, we possess the skills to propose and enact systemic legal and policy changes that can improve the health, environmental, and social impacts of the foods we produce and consume.

Through my remarks, I will share my perspective on the essential skills law schools and lawyers can offer in this field based on my own work and experience. I will first relay my personal background and journey to the field of Food Law and Policy. I will then describe how I define this field of law and share some metrics about the field's growth over the past few years. To explain what this field looks like in practice, I will

\footnotetext{
* This Essay is adapted from Emily Broad Leib's remarks at the 2015 Seattle University Law Review Symposium, Re-Tooling Food Law: How Traditional Legal Models Can Be Re-Tooled For Food System Reform, held March 6, 2015 at Seattle University School of Law. Emily Broad Leib is Director of the Harvard Law School Food Law and Policy Clinic. The author would like to thank the Seattle University Law Review for the invitation to speak; Sarah Paige and Melanie Pugh for transcription, research assistance, and editing assistance; and Ona Balkus, Alli Condra, and Baylen Linnekin for helpful feedback.

1. The term "food system" includes the different nodes in the production and consumption of food, including "production, processing, distribution, consumption, and waste management." Kameshwari Pothukuchi \& Jerome L. Kaufman, The Food System: A Stranger to the Planning Field, 66 J. AM. Plan. ASS'N 113, 113 (2000).
} 
then introduce four fundamental legal tools that make lawyers well situated to foster change in the food system. For each tool, I provide concrete examples based on my Clinic's work in this space. I end by arguing for the need for more lawyers in this field and by discussing some of the opportunities that exist for new lawyers seeking to pursue this work as a career or a passion.

\section{FINDING FOOD LAW AND POLICY}

I began my legal career in the Mississippi Delta region, in a little town an hour south of Memphis, Tennessee called Clarksdale, Mississippi. I had gone to law school to pursue a career in human rights, because I care deeply about the ways lawyers can use our profession's tools to empower individuals and communities. In my last year of law school, I learned of a fantastic opportunity to use the skills I had acquired in law school in a somewhat different manner, organizing communities around public health and economic development in the Mississippi Delta. Rather than using my legal skills to argue for vindicating human rights as I had planned during law school, my fellowship primarily involved educating community members about how to achieve their goals using the existing legal framework, building consensus about the necessary changes to that framework, and helping them to advocate for those policies that could improve their future opportunities.

Coming to that community as an outsider, I saw it as my role to listen actively in order to understand what the community wanted. What could help them achieve improved health and economic opportunity? As it turned out, food played an inextricable role in answering those questions. Community members alerted me to the need for improvement in the local food system; they told me that addressing the ways in which food was produced and sold was key to improving their health and economic opportunities.

My first food law project involved a group of farmers markets in the Mississippi Delta. In the two years before my arrival, there was a surge in the number of farmers markets in the eighteen Delta counties, growing from just two markets in 2005 to ten markets in 2010. This rapid growth triggered questions from state and local governments about how best to regulate farmers markets. Officials from various agencies rebuked or penalized the markets for breaking various laws, but the laws cited by these officials were rarely published and the markets sometimes received conflicting information from different agencies. These farmers had seen the markets as an opportunity to make some money and help feed their communities, and they wanted clear guidance so they could comply with the rules. This was my first awakening to the fact that many of the barri- 
ers to improving our food system are based in the law. I began to recognize the important role lawyers could play in helping individuals navigate and eliminate these barriers.

In order to answer the farmers' questions, I brought down a team of law students for a weeklong pro bono trip. I partnered each student with a different farmers market in an effort to understand that market's concerns and interests. Then we sat down as a group, examined their questions, found the similarities, and created a guide to respond to the common questions raised by the different markets, such as, "When do I have to charge sales tax?," "What are the food safety rules that apply?," and "When do I need to use a commercial kitchen instead of my home kitchen to prepare foods for sale?",

While many of the questions were shared among markets, some markets faced distinct challenges. For those markets, we crafted unique responses. One market operated on city-owned land next to the post office. Every year, they needed to formally ask the city's Board of Aldermen for permission to use that land for the farmers market. The Board often delayed until the last minute before giving them a response, which prevented the market from planning ahead. The market needed a longterm solution. Our students helped them draft a formal letter to the Board of Aldermen, presenting the benefits of the market and describing how giving the market a five or ten-year lease would serve farmers and the community. The Board was so surprised that a group of law students had taken an interest in the farmers market and was persuaded by the strong legal and policy arguments the students provided. The students' work helped to elevate the issue within the community. The lease was granted, and we celebrated our first success.

Throughout this project, as we explained the applicable laws to farmers markets, our research often uncovered rules that were outdated or that created barriers to beneficial business opportunities. We started thinking about what the rules should be, not just what the rules were. One example relates to sales tax. Mississippi charges the full state sales tax on all food products sold in grocery stores. ${ }^{3}$ When farmers sell food directly from the farm, however, those foods are exempt from the sales tax, an incentive intended to support agriculture in the state. ${ }^{4}$ As farmers markets became more popular, the Mississippi Tax Commission decided

2. Harvard Law Sch. Health Law \& Policy Clinic \& Harvard Miss. Delta Project, MisSISSIPPI FARMERS MARKETS: A LEGAL AND BUSINESS GUIDE (Emily Broad ed., 2011), available at http://www.chlpi.org/wp-content/uploads/2013/12/Legal-Manual-2011-Update-FORMATTED.pdf.

3. Miss. CODE ANN. § 27-65-17(1)(a) (2009).

4. Miss. CODE ANN. §§ 27-65-103(b), 27-17-365(3) (2009). 
to treat farmers markets like grocery stores, asking individual farmers to collect and remit the sales tax. This administrative burden drove farmers away from farmers markets - it encouraged them to stay home and sell from their farm, where the products were tax exempt, rather than congregate downtown, where the community could access these fresh, healthy products. By conducting research on the Mississippi sales tax, looking comparatively at sales taxes in other states and producing calculations to show that the revenue available to Mississippi from taxing farmers markets was negligible, we helped our partners make a strong case for exemption of farmers markets from the sales tax. The legislature agreed and created an explicit tax exemption for food products sold at farmers markets. $^{5}$

Through this endeavor, I saw in action the power of bringing together diverse stakeholders - farmers, consumers, community members, governmental officials - to identify and foster change. Later that year, I worked with a local nonprofit organization and various partners from around the state to create the Mississippi Food Policy Council, a volunteer coalition that "advocate[s] for food and farm policies that build healthy communities and strengthen local food systems." formalized the opportunity for these stakeholders to continually envision and push for a better food system in the state; it has now been in operation for five years and has played a key role in passing several other state food policy reforms.

Ever since my initial food law project, I have been overwhelmed by the student interest in tackling these challenges. In my two years in Mississippi, I brought sixty law students to the Delta to work on a range of projects related to food policy, health policy, and small business incubation, among others. Two enterprising students even founded a student organization devoted to this work, the Harvard Mississippi Delta Project. ${ }^{7}$ At the end of my fellowship in Mississippi, I had the opportunity to return to Harvard Law School to continue this work, and soon after, to launch the Food Law and Policy Clinic. ${ }^{8}$ The Clinic continues to work with eager students to meet the ever-growing community needs in the realm of food law and policy. And Harvard is not alone-other law

5. H.B. 1566, 2010 Leg., Reg. Sess. (Miss. 2010) (codified at Miss. CodE ANN. § 27-65-103(f) (2013).

6. About Us, MISS. FOOD POL'Y COUNCIL, https://mississippifoodpolicycouncil.wordpress.com /about/ (last visited May 4, 2015).

7. HaRvard L. SCh. Miss. Delta Project, https://orgs.law.harvard.edu/deltaproject/ (last visited May 4, 2015).

8. HARVARD L. SCH. FOOD L. \& POL'Y CLINIC, http://www.chlpi.org/food-law-and-policy (last visited May 4, 2015). 
schools are investing in opportunities for their students to study Food Law and Policy.

\section{GROWTH OF THE FOOD LAW AND POLICY FIELD}

When I started teaching Food Law and Policy and launched the Harvard Food Law and Policy Clinic, relatively few courses on Food Law and Policy yet existed, and our Clinic was the first of its kind. There were courses in Food and Drug Law and Agricultural Law, and in related topics like Animal Law, but very few courses addressed the full array of laws impacting the food system. But in the past few years, this field has exploded. In our recent article, "Food Law \& Policy: The Fertile Field's Origins and First Decade," my coauthor Baylen Linnekin and I argue that Food Law and Policy emerged as an outgrowth of two enduring areas of law: Food and Drug Law, and Agricultural Law. ${ }^{9}$ In contrast to these two fields, Food Law and Policy employs a broader and deeper lens to study the full range of agencies and actors that shape our food system. For example, when you look at a Food and Drug Law textbook, you see that food law makes up only a small part of its contents. The field also covers the laws regulating drugs, medical devices, and cosmetics. ${ }^{10}$ The field also disregards many interesting food law issues, as it is limited to regulations falling under Food and Drug Administration (FDA) jurisdiction. The field of Agricultural Law examines the laws that impact farms, but farms grow and produce many items, including fibers like cotton, that do not pertain to food. Further, Agricultural Law's analysis typically ends after those products leave the farm, though food products today often take many steps - governed by a variety of regulations - before arriving on our dinner plates as "food."

By contrast, Food Law and Policy examines the whole set of laws and regulations that govern "the food and beverages we grow, raise, produce, transport, buy, sell, distribute, share, cook, eat, and drink." ${ }^{11}$ Food Law and Policy considers FDA regulations and those promulgated by the U.S. Department of Agriculture (USDA), as well as the Environmental Protection Agency, Federal Trade Commission, and the many other agencies and governmental actors that regulate our food. The field also considers laws at different levels of government, an approach that is both

9. Baylen J. Linnekin \& Emily M. Broad Leib, Food Law \& Policy: The Fertile Field's Origins and First Decade, 2014 WIS. L. REV. 557 (2014).

10. See, e.g., Peter Barton Hutt, Richard A. Merrill \& Lewis A. Grossman, Food AND DRUG LAW: CASES AND MATERIALS (4th ed. 2014).

11. Linnekin \& Broad Leib, supra note 9, at 584. 
academically and practically valuable given the increased food policy innovation and potential for change at the state and local levels.

In measuring the growth of Food Law and Policy, Linnekin and I identified ten criteria that we believe define an academic field, ${ }^{12}$ then, using these criteria, collected relevant data on the top 100 law schools listed in U.S. News and World Report's Top Law Schools. ${ }^{13}$ Looking at criteria like courses taught, clinical projects, student food law societies, and scholarship, among others, we found that Food Law and Policy is developing rapidly as a field. As of 2013, twenty of the top 100 law schools offered at least one course in Food Law and Policy, separate from Food and Drug Law or Agricultural Law. ${ }^{14}$ Thirty clinics at twentythree schools engaged in Food Law and Policy projects. ${ }^{15}$ There had been substantial growth in scholars' use of the term "food law and policy" in academic publications as well as in publications discussing both the FDA and USDA in one article, whereas prior scholarship had treated the two agencies as doctrinally separate. ${ }^{16}$

We argue that "Food Law and Policy" emerged as a distinct field in 2004, the year that Michael Roberts taught the first course by that name at the University of Arkansas School of Law. ${ }^{17}$ The Journal of Food Law and Policy launched that academic year, also at the University of Arkansas, and since then the field has only grown. ${ }^{18}$ This trend is evidenced not just at law schools around the country but also in the news, in growing popular culture discussions, and in the interest shown by policymakers at all levels of government. Since 2004, we have seen the publication of popular books about the food system such as Fast Food Nation ${ }^{19}$ and The Omnivore's Dilemma; ${ }^{20}$ non-farmers paying attention to the Farm Bill subsidies and their impacts on our communities for the first time; ${ }^{21}$ and

12. "These factors are: (1) academic scholarship, (2) law school courses, (3) degree programs, (4) academic centers, (5) casebooks and other texts, (6) field-specific legal journals, (7) clinical and experiential education, (8) student societies and groups, (9) professional associations and bar groups, and (10) academic conferences." Id. at 586.

13. Top Law Schools, U.S. NEWS \& WORLD REPORT, http://grad-schools.usnews.rankingsand reviews.com/best-graduate-schools/top-law-schools. Our article used the 2013 law school rankings.

14. Linnekin \& Broad Leib, supra note 9 , at 599.

15. Id. at 605 .

16. Id. at 598 .

17. Id. at 590. Neil Hamilton taught a pioneering "Food and the Law" course at Drake University Law School as early as 1999. Id. However, the rest of the field did not truly coalesce until the middle of the following decade. Id.

18. Journal of Food Law and Policy, U. ARK. SCH. L., http://law.uark.edu/academics/journals/ journal-of-food-law-and-policy/ (last visited May 4, 2015).

19. ERIC SCHLOSSER, FAST FOOD NATION (2005).

20. Michael Pollan, Omnivore's Dilemma: A Natural History of Four Meals (2006).

21. Linnekin \& Broad Leib, supra note 9, at 594. 
increasing acknowledgment of obesity and diet-related diseases as some of our most pressing public health issues. ${ }^{22}$ Lawyers are often slow to adapt to changing societal trends. The response to these developments within the legal community has lagged behind that of other disciplines. However, our evidence establishes without a doubt that lawyers have arrived on the scene. The strong and growing law student and faculty interest in Food Law and Policy holds great promise for the field's future.

\section{LEGAL TOOLS IN FOOD LAW AND POLICY}

Having presented an overview of Food Law and Policy within the legal academy, I now want to talk about what it looks like to practice in this field and the crucial tools we as lawyers can bring to this work.

To start, I will describe my Clinic and the way that we practice food law and policy. Like all law clinics, the Harvard Food Law and Policy Clinic's mission is twofold. One goal is to provide services to clients, communities, and government agencies. The other is to educate students and offer them experiential learning opportunities. At the Food Law and Policy Clinic, we focus our work on four main initiatives: food access; sustainable food production; food waste; and food policy councils and food system planning. In teaching students, we offer education in a classroom, discussing the substance of food law, and in a practical setting, where students are paired with clients and have the opportunity to sharpen the skills needed to excel in this work. Our Clinic does not practice in the courtroom; instead, we teach students how to operate in the policy advocacy arena. Students can develop a range of transferable skills, including researching and writing policy briefs; composing legislation and regulations; commenting on proposed rules; conducting interviews and fact-finding; and training communities about advocacy, the food system, and policy change. We help students to think deeply about our clients' needs and try to understand where their challenges reside: in the law itself, in its implementation, in public understanding of the law, or elsewhere. This approach to addressing clients' issues tracks what law students will need to do to in order be successful and have an impact when they leave law school.

Great demand exists for fundamental reform of our food system, and lawyers are uniquely situated to consider both the specific impacts and systemic challenges arising from the laws we currently have in place. As lawyers, we bring four main tools to this work: litigation, education, 
transactional assistance, and policy advocacy. These tools are not unique to food policy, but they are unique to lawyers. To demonstrate the essential nature of these tools to food system change, below are examples of how we can apply these skills to address the range of needs emerging in this arena.

\section{A. Litigation}

When most non-lawyers envision lawyers, they picture us in a courtroom. Having the option to use litigation within the food system certainly helps deter the worst industry practices. In recent years, attorneys have used the courts to stop the deceptive practices of some food businesses, like foods bearing the label "natural" that included genetically modified ingredients or synthetic additives. ${ }^{23}$ Along the same lines, plaintiffs have brought litigation against companies labeling meat products as "humanely raised" when the animals were raised under conditions that would not seem humane to the average consumer. ${ }^{24}$ Right now, however, many of the laws regulating the food system are not conducive to the food system most Americans would like to see. The laws support the status quo; privilege the existing food industry; and include exemptions for farms - often referred to as "agricultural exceptionalism" 25 that allow those farms to impose many negative externalities on society. Without adequate laws that reflect goals for healthier and more sustainable food production, advocates using litigation as an avenue for change are struggling to succeed in court. Thus, many of the other tools of lawyers are in high demand to foster systemic change and support new alternatives within the food system.

23. See, e.g., Williams v. Gerber Prods. Co., 552 F.3d 934 (9th Cir. 2008) (holding that plaintiffs could survive a motion to dismiss their California unfair competition and consumer protection claims where baby food was advertised as natural and containing real fruit though the two most prominent ingredients were corn syrup and sugar); Holk v. Snapple Beverage Corp., 575 F.3d 329 (3d Cir. 2009) (holding that state law claims about use of the term "all natural" in advertising were not preempted by the Federal Food, Drug and Cosmetic Act (FDCA)); Pappas v. Naked Juice Co of Glendora, Inc., No. LA CV11-08276 JAK, 2012 WL 1925598 (C.D. Cal. May 14, 2012) (where the court indicated unwillingness to dismiss California state law consumer protection claims for the use of the term "all natural" on fruit juice containing genetically modified foods, since whether the claims were deceptive was a question of fact for the jury).

24. Hemy v. Perdue Farms, Inc., 2013 WL 1338199 (D.N.J. Mar. 31, 2013) (holding that plaintiffs could survive a motion to dismiss their claims under the New Jersey Consumer Fraud Act and common law fraud, among others).

25. Susan A. Schneider, A Reconsideration of Agricultural Law: A Call for the Law of Food, Farming, and Sustainability, 34 WM. \& MARY ENVTL. L. \& POL'Y REV. 935, 935-36 (2010). 


\section{B. Education}

One of the most useful skills lawyers possess is the ability to read a statute or regulation and explain it in lay terms to a non-lawyer. Often, small or new businesses need step-by-step explanations of the laws and regulations that impact their livelihoods. Such work can democratize the food system, allowing small farmers or fledgling food entrepreneurs access to the information they need to be successful. As an example of this work, we helped the City of Boston prepare a guide to the licensing and zoning processes that new food truck vendors must undergo after the City began permitting food trucks in $2012 .{ }^{26}$ Alongside the guide, we conducted trainings at City Hall for aspiring food truck vendors. When Boston amended its zoning code in 2014 to allow urban agriculture, we helped the City create a similar guide for urban farmers. ${ }^{27}$

We play an analogous role with groups of food advocates, like food policy councils, to give them ideas and strategies for how to create policy change at the federal, state, and local levels. For example, we are working with advocates in Navajo Nation to develop a toolkit that catalogues the laws and policies that impact their food system. These advocates want to increase food sovereignty in the Navajo Nation, and recognize the importance of policy in realizing that goal. Navajo Nation suffers from extreme rates of obesity and diabetes. Around $22 \%$ of the Navajo population is living with diabetes, ${ }^{28}$ compared with $9.3 \%$ of the population nationally. ${ }^{29}$ Regions of Navajo Nation have obesity rates ranging from $23 \%-60 \%,{ }^{30}$ much higher than the national average. These high rates of diet-related disease are linked with the lack of access to healthy, fresh foods in the vast, rural Nation. As of 2014, there were only ten full service grocery stores in Navajo Nation, an area the size of West Virgin-

26. Harvard Food LaW \& Policy Clinic, Cmty. Enter. Project of Harvard TRANSACTIONAL LAW CLINICS \& CITY OF BOSTON MAYOR's OFFICE OF FOOD INITIATIVES, FOOD TRUCK LEGAL TOOLKIT (2013), available at http://www.cityofboston.gov/images_documents/Food \%20Truck\%20Legal\%20Toolkit\%20PDF\%2012.18.13_tcm3-43273.PDF.

27. Allison CONDRA et AL., HARVARd FoOd LAW \& POLICY Clinic, URban Agriculture In Boston: Permits and Approvals NeEded to Start Your Less than ONE ACRE GroundLEVEL FARM (2014), available at http://www.chlpi.org/wp-content/uploads/2013/12/Boston-UrbanAgriculture_Less-than-1-Acre-Guide_July-2014_Complete1.pdf.

28. Navajo Nation, PARTNERS IN HEALTH, http://www.pih.org/country/navajo-nation/about (last visited Apr. 18, 2015).

29. Statistics About Diabetes, AM. DiABETES Ass'N, http://www.diabetes.org/diabetes-basics/ statistics/ (last visited May 4, 2015).

30. Healthy Dine Nation Act of 2014, Res. CN-54-14, 22d Leg. (Navajo Nation 2014). 
ia. ${ }^{31}$ Within one of these grocery stores, $80 \%$ of food was unhealthy, processed food. ${ }^{32}$

Yet, advocates wanting to increase access to fresh, wholesome foods in Navajo Nation face a confusing legal environment and their efforts are not always supported by existing governmental policies. For example, Navajo Nation spans portions of three states: Arizona, New Mexico, and Utah. Because state governments, instead of the Navajo government, administer the Supplemental Nutrition Assistance Program (SNAP, formerly food stamps), Navajo residents are subject to different eligibility standards and enrollment procedures depending on where they live within the Nation. This makes it impossible for Navajo authorities to set their own eligibility criteria for the program or conduct helpful outreach and technical assistance for eligible families. In addition, it can lead to disparities in access across the Nation. In helping educate community members about applicable laws that affect Navajo Nation, we hope to enable them to support production of and access to food that is healthy, culturally appropriate, and economically profitable for the Nation.

Providing education about legal rules is one of a lawyer's most powerful tools. Yet providing such education often uncovers the need to use other important tools, including transactional expertise and policy advocacy.

\section{Transactional Assistance}

Another key tool of lawyers is the ability to help individual clients with their transactional needs. In the context of the food system, consumer preferences are changing, unlocking new business opportunities for farmers and food entrepreneurs. Sometimes education and training help to provide a starting place for aspiring entrepreneurs, but to take the next steps, many businesses need tailored assistance with things like reviewing a lease, drafting a contract, or incorporating with a formal business structure. Lawyers provide counsel to a range of actors in the food system. Although most big companies can readily afford in-house counsel to help them read and understand rules, small farmers and entrepreneurs do not have that luxury and their businesses suffer for it. We can help.

31. DinÉ Policy INST., DinÉ FoOd SOVEREIGNTY: A REPORT ON THE NAVAJO NATION FoOD

System And the Case to Rebuild a Self-Sufficient Food System for the DinÉ People 54 (2014), available at http://www.dinecollege.edu/institutes/DPI/Docs/dpi-food-sovereignty-report.pdf.

32. Id. at 17. 
Recognizing this need for free or low-cost transactional legal services, the Conservation Law Foundation, one of our partners, launched the Legal Services Food Hub, a clearinghouse network that connects attorneys interested in providing pro bono service to small farmers and food entrepreneurs in need of such services. ${ }^{33}$ Their first Hub operates in Massachusetts, though they plan to expand to other states throughout the New England region. In order to support this important work, we joined the project to create guides for the lawyers in the network. ${ }^{34}$ In so many other areas of law, lawyers can find resources, such as restatements or treatises, that make it easier for them to do their work. In this relatively new field, however, materials that identify and explain the relevant law are scarce. We hope that by creating these guides, we can reduce the barriers for attorneys working on these matters and encourage more attorneys to join the network. Outside of this project, many other initiatives are springing up to meet these needs as the number of small and new farmers and entrepreneurs continues to grow. ${ }^{35}$

\section{Policy Advocacy}

The last tool, the one we use most heavily in my Clinic, is policy advocacy. As lawyers, when we educate and serve multiple clients, we begin to recognize systemic problems like outdated or unfounded laws, and we can identify opportunities for improvement. Over time, our food system has become increasingly national and even global in scale. Food is big business, and the laws developed to regulate big businesses often do not make sense for small or early-stage entities. One place in particular where our laws are not well suited to small producers is in the area of food safety. ${ }^{36}$

As the FDA was writing rules the past few years to implement the Food Safety Modernization Act (FSMA), many were concerned that these rules would needlessly burden small farmers. We undertook a project to comment on the FDA's draft rules to try to avoid this outcome. Our client, the National Sustainable Agriculture Coalition, coordinated a mul-

33. Legal Services Food Hub: A Project of the Conservation Law Foundation, http://www.legalservicesfoodhub.org/ (last visited May 4, 2015).

34. Allison CONDRA et al., Harvard Food LaW \& Policy Clinic, Farm AND Food LaW: A GUide fOR LAWYers IN THE Legal SERVICES FoOd Hub NeTWORK (2014), available at http://www.chlpi.org/wp-content/uploads/2013/12/Farm-and-Food-Law-Guide_June-20-2014.pdf.

35. See, e.g., FARM COMMONS, http://farmcommons.org/ (last visited May 4, 2015); Organizations and Transactions Clinic, STANFORD L. SCH., https://www.law.stanford.edu/organizations/ clinics/organizations-and-transactions-clinic (last visited May 4, 2015).

36. Emily M. Broad Leib, The Forgotten Half of Food System Reform: Using Food and Agricultural Law to Foster Healthy Food Production, 9 J. FOOD L. \& POL’Y 17 (2013). 
tidisciplinary group of organizations to analyze concerns with these lengthy and complicated rules. Our Clinic focused on the provisions exempting small and mid-size farms from the FSMA rules. In the initial proposed rules, the vague language made it too easy for small farms to lose their exemptions, without any option to regain those exemptions. Our comments highlighted these issues, illustrating how the regulations would likely apply in practice and recommending new language to preserve procedural protections for small farms. ${ }^{37}$ In response to the comments we and others submitted, the exemptions were edited and clarified in the FDA's amended proposed rule.

In addition to helping the National Sustainable Agriculture Coalition with their comments, we also submitted comments on behalf of the Clinic. I want to underscore this point. Even though we are lawyers working for clients, we are also food system stakeholders. We are all consumers, we all eat, and we all suffer the consequences of poor food regulations. Thus, we have equally legitimate standing to make our voices heard by commenting on legislation or regulations that impact our food system. I encourage those of you interested in these issues to engage in this way-you too can submit comments on proposed rules, or send letters to Congress on pending legislation that impacts the food we eat. $^{38}$

Another area where we have used policy advocacy as a tool is around the topic of food waste. ${ }^{39}$ Action to reduce this waste is urgentwe currently throw away almost forty percent of the food produced in this country. ${ }^{40}$ We serve immense portions, we do not eat our leftovers, and we do not flinch at throwing away food when the "sell by" date passes, even though the food is still perfectly safe and wholesome. Many of our laws perversely lead to more wasted food and make it hard to recover food to distribute to those in need. To explore this issue, we examined the laws surrounding date labels and published a report in partner-

37. Emily Broad Leib \& Allison Condra, Re: Comments on FDA Proposed Rule for the Standards for Growing, Harvesting, Packing, and Holding of Produce for Human Consumption, 78 Fed. Reg. 3504 (Jan. 16, 2013), Docket No. FDA 2011-N-0921, available at http://www.chlpi.org/wpcontent/uploads/2013/12/HLS_FLPC_Produce_Safety_Rule_Comment_FINAL.pdf.

38. Comments may be submitted electronically through the following website: http://www.regulations.gov/\#!home.

39. Emily M. Broad Leib \& Dana Gunders, Natural Res. Def. Council, The Dating GAME: How CONFusing Food Date LABels LeAD TO FoOd WASTE IN AMERICA 3 (2013), available at $\mathrm{http} / /$ /blogs.law.harvard.edu/foodpolicyinitiative/files/2013/09/dating-game-report.pdf.

40. See Dana Gunders, Natural Res. Def. Council, Wasted: How America Is Losing UP TO 40 PERCENT OF ITS FOOD FROM FARM TO FORK TO LANDFILL (2012), available at http://www.nrdc.org/food/files/wasted-food-IP.pdf. 
ship with the Natural Resources Defense Council. ${ }^{41}$ We found that there are generally no federal regulations regarding date labels on food. ${ }^{42} \mathrm{Be}-$ cause the federal government does not regulate these dates, states are not preempted from passing laws. Forty-one states have chosen to require a dizzying array of date labels on at least some foods, ${ }^{43}$ and twenty states go further and restrict or bar sales of certain past-date foods. ${ }^{44}$ These regulations are not related to food safety and often have no scientific basis. ${ }^{45}$ In regulating milk products, for instance, some states, like New York, do not require any label ${ }^{46}$ some require labels on cream but not milk; ${ }^{47}$ and some states require that the date put on the label is a certain number of days after pasteurization - in Pennsylvania, the date must be seventeen days after pasteurization, ${ }^{48}$ and in Montana it must be twelve. ${ }^{49}$ The lack of consistency among these state laws further proves that they are not based in science related to food safety.

Even though date labels are not well regulated and are not linked with safety, ${ }^{50}$ nine out of ten Americans say that they throw food away once the date passes. ${ }^{51}$ Using our legal tools, we were able to demystify this area of law. Our work in this area has allowed us to raise awareness about an inconsistent and ill-conceived area of law that often undermines our goals of safety and access, and we are now pushing for systemic change to help improve outcomes in this area in the future.

\section{CONCLUSION}

The past few years have seen a groundswell of community attention focused on supporting a safer, healthier, and more sustainable food supply. We in the legal profession have the tools to help strengthen this movement. None of the tools that I discussed-litigation, education, transactional assistance, and policy advocacy-are unique to food law.

41. See BROAD LEIB \& GUNDERS, supra note 39.

42. Id. at 9-11. The one exception is infant formula, which under FDA regulation is required to bear a "use by" date based on tests showing that the concentration of nutrients is adequate for the health of children up to the marked date. Id. at 11 (citing 21 C.F.R. $\S 107.20$ (2012)).

43. Id. at 12 .

44. Id.

45. See id.

46. See id. at 48.

47. N.H. REV. STAT ANN. § 184:30-g (2013).

48. 7 PA. CODE § 59a.15 (2013).

49. MONT. ADMIN. R. 32.8.101 (2013); MONT. ADMIN. R. 32.8.203 (2013).

50. According to the Office of Technology Assessment (OTA), which existed as an office of the U.S. Congress from 1972 to 1995, "there is little or no benefit derived from open dating in terms of improved microbiological safety." BROAD LEIB \& GUNDERS, supra note 39, at 6. (2011)).

51. Id. at 19 (citing Food MKtg. InSt. RESEARCh, U.S. Grocery SHOPPER TRENDS 144 
These are the tools that lawyers possess, the tools we practice in law school, and the tools that we continue to hone throughout our careers. In each area I have discussed, the need for lawyers far outstrips our available resources. This field needs you.

The growing interest and need among farmers, entrepreneurs, and communities means that meaningful career opportunities exist. We have seen increasing numbers of our former students and interns making careers in this space. For those who want to build a career in Food Law and Policy, there is much work to do and I am confident that the professional landscape will only continue to expand. We periodically publish a career guide with food policy jobs and internships, and the list of opportunities grows in each edition. ${ }^{52}$ Those interested in such a career need to be entrepreneurial because while there is immense need, we are still building this field brick by brick.

The great need also creates room for commitment at different levels of engagement. Even if Food Law and Policy is not a career aspiration, lawyers in a variety of practice settings can use their skills to provide food law and policy assistance on a pro bono or ad hoc basis. The opportunities are endless, whether it means helping your neighborhood school to source more local produce, assisting small local farms in organizing a farmers market, or adding your well-reasoned voice to a local food policy council.

Whatever your path, the project of building Food Law and Policy is incredibly exciting, and I am thrilled that so many of you share my enthusiasm for and commitment to this effort. I hope to see you all in the field!

52. HARVARD FoOd LAW \& POLICY CliniC \& HARVARD FOOD LAW SOC'Y, FOOD LAW AND POLICY CAREER GUIDE (3d ed. 2014), available at http://www.chlpi.org/wp-content/uploads/ 2013/12/2014-Food-Law-and-Policy-Career-Guide_FINAL2.pdf. 